\title{
Mapping learning difficulties in general chemistry course
}

\author{
Asyti Febliza*, Putri Ade Rahma Yulis \\ Chemistry Education, Faculty of Teacher Training and Education, Universitas Islam Riau, Pekanbaru-Indonesia
}

\begin{abstract}
:
Many first semester students in University struggle to study chemistry, it proven by low achievement of students in learning general chemistry. This study investigated student's difficulties to understand in term of chemistry material characteristics (fundamental concept, advanced concept, mathematical concept and misconception) and learning process in the class. This investigation includes a coginitve test and a difficulty questionnaire were given to 92 first semester students in Biology program Universitas Islam Riau-Indonesia who took general chemistry course. Research questions in this study were: 1) What topics did students find difficult?; 2) Which chemistry material indicators did students feel difficult?; 3) How did student's perceptions about learning chemistry before and after learning process in college? The result gave information that student's difficulties mostly existed in average level in chemical bonding about 84 students, stoichiometry around 52 students and higher level of barrier in colligative properties topics reached 52 students. Furthermore, students felt higher difficult in three indicators in term of mathematical concept, advanced concept and misconception with number reached $46 \%, 65 \%$ and $61 \%$ respectively. Difficulty questionnaire showed the slightly dropping around $9 \%$ before and after learning process. Overall, the difficulties encountered in average level and higher level. Topic that sudents felt difficult were: chemical bonding, stoichiometry and colligative properties, which each topic contained higher skill such as advanced concept, mathematical skill and misconception. The minor dip in student's perception can give us information about quality changes after learning process.
\end{abstract}

\section{Keywords:}

basic chemistry; learning difficulties indicator; student's difficulties; students's perception

\section{Introduction}

Many students suppose that chemistry is difficult subject. Some research identified that students difficult to understand fundamental chemistry concept and advanced concept in chemistry Woldeamanuel et al., 2014, and Saritas, 2015 identified students Challenged to understand chemical concepts, structures, and processes at particulate level and making connection in macro level.

Learning difficulty means a understanding problem or emotional difficulty that affect to student's ability to learn. Learning difficulty is associated with intrinsic and extrinsic factors. Students who faced such barriers are more likely to fail in their exam marks. Students age $15-18+$ had weakness in advanced concepts and mathematical concepts in Irlandia (Childsa \& Sheehan, 2009. The lack of mathematical was

\footnotetext{
* Corresponding author. asytifebliza@edu.uir.ac.id doi: https://doi.org/10.2 4114/jpkim.v10i2.10772
}

greater source of difficulty among biology student in higher education (Scot, 2016). Similary to this finding, lack of proper understanding of basic concepts and principles in chemistry and also mathematical skills limit students understanding of certain topics, such as atomic structure, rates of chemical reaction and energy, chemical reaction, rates of chemical reactions and energy effects (Akani, 2017). Other researchers also found student's difficulties in encountered assosiaciation concept in colligative properties topic, occurred predominantly on the most abstract level and also the symbolic level, such as atomic models change (Thomson, Rutherford, Bohr, Bohr-Sommerfeld), to solve this problem teacher may presented explicitly and in a concrete visualizing by experimental evidence (Cardelini, 2012; Sokrat et al., 2014; Silaban \& Simangunsong, 2015). explained that one of way to make concrete visualizing with experimental evidence by using interactive multimedia (Febliza \& Afdal 2015). 
Many first semester students in University struggle to study chemistry, it proven by low achievement of students in learning general chemistry. First semester students in Biology programs Universitas islam Riau-Indonesia show low achievement in basic chemistry course, approximately $90 \%$ students get exam marks less than 60 every semester over five years in each class. This study investigated student's difficulties to understand in term of chemistry material characteristics (fundamental concept, advanced concept, mathematical concept and misconception) and learning process in the class. This investigation includes a coginitve test and a difficulty questionnaire were given to 92 first semester students in Biology program Universitas Islam Riau-Indonesia who took general chemistry course.

Research questions in this study were: What topics did students find difficult, which chemistry material indicators did students feel difficult and how did student's perceptions about learning chemistry before and after learning process in college?

\section{Materials and Methods}

The general chemistry course is offered in first semester for biology program in Universitas Islam Riau. This descriptive study used percentage to present student's difficulties that collected from 92 first semester student in Biology Program Universitas Islam Riau. Sampling technique was purposive sampling because of low exam marks of in general chemistry course in Biology program Universitas Islam Riau. Pursposive sampling is a nonprobability sampling that selected by judgmental or selective purpose (Febliza \& Afdal, 2015)

Research instrument used cognitive test for 6 topics which given after each topic finished and difficulty questionnaire given before learning process and after learning process. Research procedure can be seen in Fig 1 .

The cognitive test questions were designed to identify student's barrier in material characteristics, for instance: fundamental concept, advanced concept, mathematical concept and misconception). Each topic be composed of 30 questions. The score for each student were analyzed by using the following formula:

Score $=\frac{B}{n} \times 100 \%$

B: Correct answer

n: Total questions

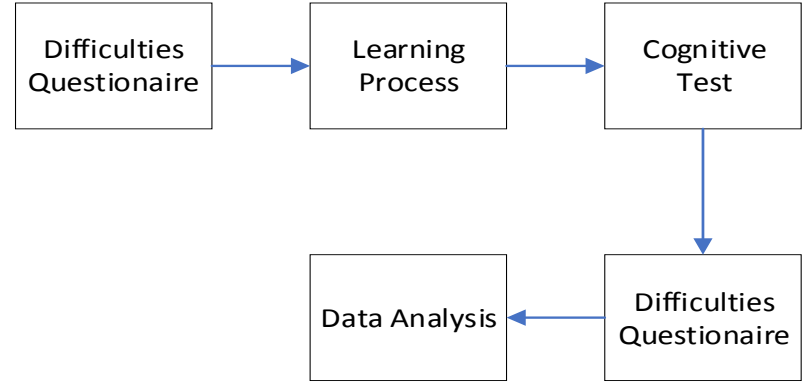

Fig 1. Research procedure.

The result represented by using reference classification in Table 1.

Table 1

Difficulty reference classification (Modification from Arikunto, 2013).

\begin{tabular}{ccc}
\hline $\begin{array}{c}\text { Numbe } \\
\mathbf{r}\end{array}$ & $\begin{array}{c}\text { Score } \\
\text { Interval }\end{array}$ & $\begin{array}{c}\text { Difficulties } \\
\text { Classification }\end{array}$ \\
\hline 1 & $80-100$ & Lower extreme \\
2 & $60-79$ & Lower \\
3 & $40-59$ & Average \\
4 & $20-39$ & Higher \\
5 & $0-19$ & Upper Extreme \\
\hline
\end{tabular}

Difficulty questionnaire was given to identify student's perception about why chemistry is difficult? Questionaire questions were arranged by 4 difficulty indicators such as: general difficulty, material characteristic difficultiy, learning process difficulty in the class, and learning process support outside the class. Questionaire used rating scale with 5 level agreement. 5 indicated as high level of agreement of students who felt highest difficulty, 4 quatified higher difficulty, 3 for average difficulty, 2 for low difficulty and 1 as lower level of difficulty. Difficulty questionnaire consisted of 45 statements. All of statements in difficulty questionnaire were in negative statement which calculated by using formula:

Response $=\frac{C}{N} \times 100 \%$

C: Agreement level choice

N: Total high level agreement

Student's response will be measured in percentage of difficulty indicators for all student's response and interpreted by using difficulty reference classification in table 2 . Difficulty questionnaire was designed by modification of Student Questionnaire TIMSS 2007. TIMSS (Trends in International 
Mathematics and Scince Study) has been measuring student attitudes toward mathematics and science achievement since 1995.

Table 2.

Difficulty reference classification (Modification from Arikunto, 2013).

\begin{tabular}{ll}
\hline \multicolumn{1}{c}{ Percentage } & \multicolumn{1}{c}{ Category } \\
\hline $0 \%$ & Zero \\
$1 \%-25 \%$ & Fewer extreme \\
$26 \%-49 \%$ & Fewer \\
$50 \%$ & Average \\
$51 \%-75 \%$ & Higher \\
$76 \%-99 \%$ & Higher extreme \\
$100 \%$ & Wholly \\
\hline
\end{tabular}

\section{Results}

The result of student's cognitive test for 6 topics can be seen in Fig 2 .

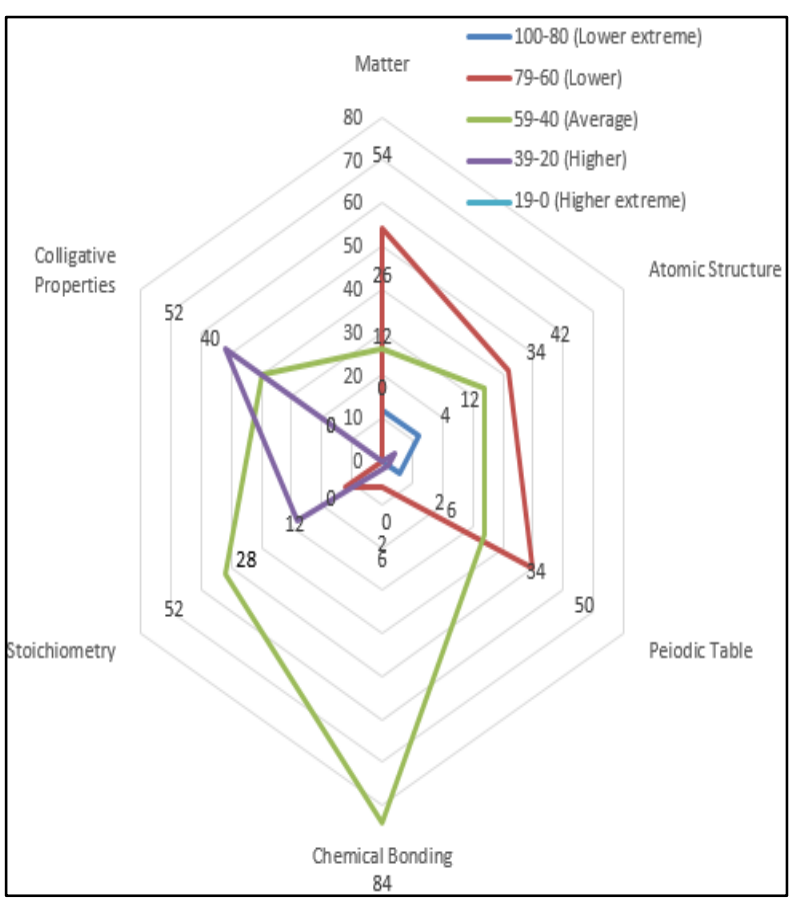

Fig 2. Student's exam marks for 6 topic in general chemistry course.

Fig 2, gave information about number of students (from total 92 students) who got barrier in each topic in general chemistry course. Overall, most of students experienced average barrier level in each topics of general chemistry course, as number 84 students in chemical bonding topic, 52 students in stoichiometry topic, 40 students in colligative properties topic, 26 students in matter topic, 34 students in both atomic structure and periodic table topics. The higher level of barrier being evident in colligative properties and stoichiometry topics reached 52 students and 28 students respectively. Topics that students supposed as low difficulty were three topics in term of matter, atomic structure, and periodic table that claimed by less than 54 students.

Cognitive questions were designed by four indicators of student's difficulty in chemistry about: fundamental concept, mathematical concept, advanced concept, and misconception. The result of student's difficulty in cognitive test, Showed in Fig 3.

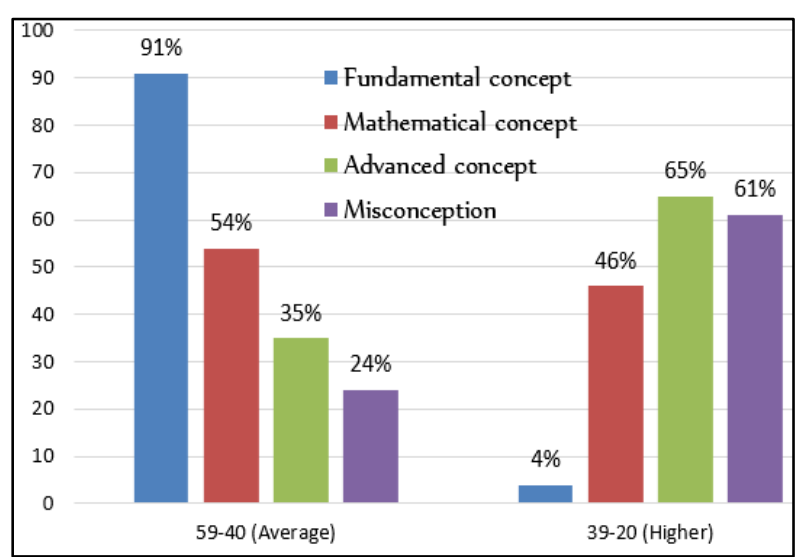

Fig 3. Average of student's difficulty in chemistry concept per indicator.

Fig 3, showed the higher level of difficulties were in mathematical concept, advanced concept and misconception, as number of difficulties about $46 \%, 65 \%$ and $61 \%$ respectively. The highest number of students who had average level of difficulties reached $91 \%$ in fundamental concept. Student's difficulties in average level expericed a slight fall for three indicators, as numbers dropped marginally from around 54\% in mathematical concept, $35 \%$ in advanced concept and $24 \%$ in misconception.

Difficulty questionnaire was given to identify student's perception about chemistry. The data about student's perception about in chemistry expressed in Fig 4.

The data in Fig 4, presented student's perception about chemistry before and after learning process. Overall, more than $50 \%$ students claimed that chemistry difficult before learning process, the highest number of difficult reached $66 \%$ when students learned chemistry in the class, about $59 \%$ felt barrier in learning process support outside the class, around $62 \%$ found difficulty in chemistry material 
characteristic and $60 \%$ for general difficulty. The number of student's perception declined around 9\% for each indicator. Approximately 57\% expressed the same number of difficulties in three indicators in term of general difficulty, chemistry material characteristic and learning process in the class. Then, student's barrier in learning process support outside the class reached $48 \%$.

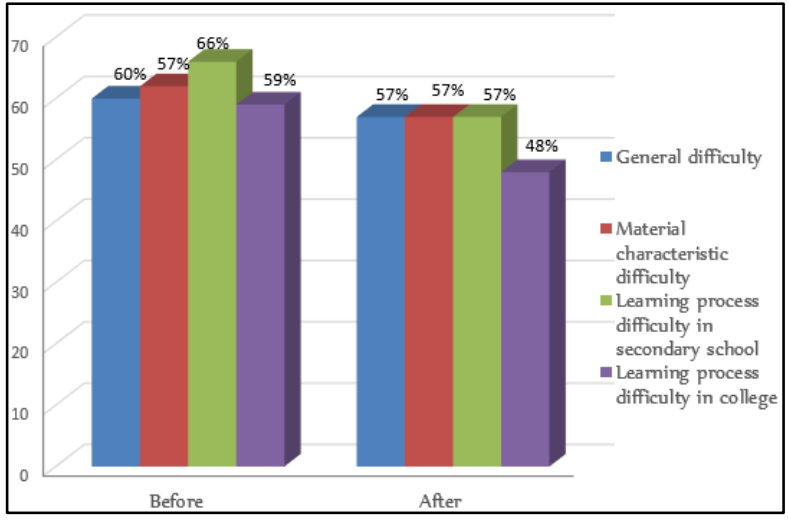

Fig 4. Difficulty questionnaire before and after learning process.

\section{Discussion}

The result of student's cognitive test for 6 topics gave information that student's difficulties mostly existed in average level in chemical bonding about 84 students, stoichiometry around 52 students and higher level of barrier in colligative properties topics reached 52 students. The other found that colligative properties were the most difficult concept for students (Sokrat et al., 2014; Manalu et al., 2016). In contrast to this study, Cardellini, L (2012) identified that student's difficuly occurred predominantly on atomic models change (Thomson, Rutherford, Bohr, Bohr-Sommerfeld), yet in this study only 34 students supposed that atomic structure difficult in average level of barrier.

If we look at chemistry material indicators result in figure 3 , students felt higher difficult in three indicators in term of mathematical concept, advanced concept and misconception with number reached $46 \%, 65 \%$ and $61 \%$ respectively. Other researcher found student's weakness in advanced concepts, mathematical skill, understanding of basic concepts and principles in chemistry, and also in encountered assosiaciation concept (Childsa \& Sheehan, 2009; Cardelini, 2012; Sokrat et al., 2014; Woldeamanuel et al., 2014; Scot, 2016; Akani, 2017; Manalu et al., 2017)
Regarding to difficulty questionnaire before and after learning process got information that before learning process perceived higher difficult than after learning process. Declining of difficulty approximately under than $9 \%$, although slightly dropped, but it can be indicated that quality changes after learning process. Indicators of learning process difficulty in the class and support outside class showed the same dropping around 9\%, which $66 \%$ decreased to $57 \%$ for learning process difficulty in the class and $59 \%$ into $48 \%$ for learning process support outsite the class indicator. Both general difficulty indicator and material characteristic indicator showed fewer declining compared with two others before. As number dropped from $60 \%$ to $57 \%$ and $62 \%$ to $57 \%$ in order for general difficulty indicator and material characteristic indicator. If we compared between three findings in this study, we got information that learning process in the class and support from outside affected to student's achievement.

\section{Conclusion}

Overall, the difficulties encountered in average level and higher level. Topis that sudents felt difficult were: chemical bonding, stoichiometry and colligative properties, which each topic contained higher skill such as advanced concept, mathematical skill and misconception. Student's understanding in those skill (advanced concept, mathematical skill and misconception) perceived higher level of difficulty. Student's perception about learning process before and after learning process showed slightly decresed, this minor dip can give us information about quality changes after learning process.

\section{Acknowledgments}

We are very grateful to the Lembaga Penelitian dan Pengabdian kepada Masyarakat (LPPM) Universitas Islam Riau as funder in this research and to all colleagues who contributed in this study.

\section{References}

Akani. (2017). Identification of the Areas of Students Difficulties in Chemistry Curriculum at the Secondary School Level. Inter J Emerging

Trends Sci and Technol 4(4), 5071-5077.

Arikunto, S.(2013). Prosedur Penelitian Suatu Pendekatan Praktik. Jakarta: Rineka Cipta. 
Cardellini, L. (2012). Chemistry: why the subject is difficult?. Edu Quimica, 23, 305-310.

Childsa, P. \& Sheehan, M. (2009). What's difficult about chemistry? An irish perspective. chemistry education. Resh and Practice, 3(10), 204-218.

Febliza, A. (2018). Pengaruh penerapan multimedia interaktif dengan pembelajaran inkuiri pada topik kesetimbangan dalam larutan terhadap hasil belajar mahasiswa kimia. Perspektif Pendidikan dan Keguruan 9(1), 1-6.

Febliza, A. \& Afdal, Z. (2015). Statistika dasar penelitian Pendidikan. Adefa grafika, Pekanbaru.

Manalu, E., Silaban, S., Silaban, R., \& Hutabarat, W. (2016). The development of chemical practice guidebook colloid system-based integrated contextual character values. Jurnal Pendidikan Kimia, 8(2), 8-13.

Manalu, H. C., Hutabarat, W. \& Silaban, S. (2017). The Development of Cooperative Learning Model Type Teams Games Tournament (TGT) Integrated on Scientific Approach. ICIESC, 6-11.
Saritas., M.T. (2015). Chemistry teacher candidates' acceptance and opinions about virtual reality technology for molecular geometry. Academic J Edu Res and Rev, 10(20), 2745-2757.

Scot., F.J. (2016). An investigation into students' difficulties in numerical problem solving questions in high school biology using a numeracy framework. European J Sci and Math $E d u, 4(2), 115-128$.

Silaban, S. \& Simangunsong, N.S.D. (2015). Pengaruh model pembelajaran Contextual Teaching and Learning (CTL) terhadap hasil belajar siswa pada pokok bahasan sistem koloid. Jurnal Pendidikan Kimia, 7(01), 95-101.

Sokrat, H., Tamani, S., Moutaabbid, M. \& Radid, M. (2014). Difficulties of students from the faculty of science with regard to understanding the concepts of chemical thermodynamics. Procedia-Social and Behavioral Sciences, 116, 368-372.

Woldeamanuel, M. M., Atagana, H. \& Engida, T. (2014). What makes chemistry difficult? African J Chem Edu, 4(2), 31-43. 